\title{
Translator's Consciousness and Historical Literature Translation
}

\author{
Xin Hui \\ Jinan University, Tianhe District, Guangzhou City, Guangdong Province, 510632, China \\ 77165061@qq.com
}

\begin{abstract}
China's translation history enjoys a long history. Since the creation of writing, Chinese scholars have taken the issue of "standard" of translation as one of the central topics of research. Although there are different schools of China's translation theory, no signs of continuity have shown. In the process of argumentation of translation theories, either too much emphasis is placed on "literal translation" and "rigid translation" while ignoring the readability of the translated work; or too much emphasis is placed on the artistic value of the translated text while ignoring the value orientation of the original author. In the generalization process of the translation theories, the invalidity to justify core point failed to achieve coherence. Inadequate mention of cultural context leads to the "dislocation" between translation theory and translation practice. Translators conduct translation activities by "self-consciousness" without the guidance of specific theories. Since the 1960s, with the development and changes of historical theories, the form and content of historical texts have undergone fundamental changes, merging literature, philosophy, natural science, art and other elements, integrating into a comprehensive discipline. At the same time, the emergence of "linguistic turn" and "cultural turn" has redefined the research object, research category and research method of translation theory, providing necessary theoretical support for historical translation. Based on the translation theories between China and the West, combining history and translation practice, this paper puts forward the concept of "Affinity Theory" between translator's consciousness and historical translation with the purpose of providing a mode of feasibility for historical translation.
\end{abstract}

Keywords: Affinity; Historiography; Translator's Consciousness and Historical Text.

\section{China's Translation Wave and Translation Thought}

Generally speaking, there are three major waves of translation as we take China's translation history into account: Zhi Qian, an early translator of Buddhist scriptures, proposed to adhere the translation method of "Follow the original meaning, without decoration" (Luo X\& Chen Y Ed, Analects on Translation. Beijing: Commercial Press, 2009, p.22.) with reference to the differentiation between Chinese and Indian culture as they belong to "different naming system and categories, so it is extremely difficult to translate from one language to another" (Ibid, p.22.). Master Xuan Zang pursued the principle of "Smoothness in translated text and flawless in meaning", focusing on the graceful and precise expression of the meaning in the text. Buddhist scripture translation promotes the exchange and integration between China and foreign cultures, laying a solid foundation for the formation of translation thoughts. The second wave of translation starts with scientific translation, which prevails in the late Ming and early Qing dynasties. During this period, the body of translation were "the western Jesuits who came to China to preach, and the Chinese literati who were engaged in scientific research or interested in science" (Ibid, p.155). In due time period, they translated more than 120 kinds of scientific works: Elements of Euclid by Xu Guangqi; Map of Nations by Matteo Ricci's "Atlas of the World" are representatives. After the wave of scientific translation, social science translation gradually stepped onto historical stage. The Four Continents Annals translated by Lin Zexu and the illustrated annals of overseas countries compiled by Wei Yuan turned to be the first set of historical and geographical translations with the aim "to see the world from a broad perspective", while Yan $\mathrm{Fu}$, whose translation work Evolution and Ethics and translation principles of "faithfulness", "expressiveness" and "elegance" have profound and ever-lasting influence on later generations. Since the Literary Revolution, the "new generation" of translators have generated various theories with absorption of foreign cultures: Lu Xun's theory of "faithfulness and smoothness", Lin Yutang's "Standard of faithfulness, smoothness and artistic value", Zhu 
Guangqian's "translation art theory" are an epitome of this period. However, as Wang Guowei , a learned scholar in the late Qing dynasty proposes in the article on the Input of New Learning Language, he argues that China "has argumentation but no logic, literature but without grammar; abstraction and classification, both of which are not our advantages". ( Luo X\& Chen Y Ed, Analects on Translation. Beijing: Commercial Press, 2009. p.259-261.) To propose a criterion to determine the scope of translation of social science materials, scholars of recent and contemporary times have made in-depth exploration on this issue. Ma Jianzhong, a grammarian proclaims to make proposal for the Establishment of a Translation Academy ... with a purpose "to analyze the complexity and simplicity of its words, to make in-depth study into its stylistic varieties, and to explain the profound and subtle changes in its meaning and principles ...all of which contribute to make sure that the translated text is appropriate for its original, without changing the embedded meaning. A good translation could benefit the reader as he reads the original" (Ibid, p.192).

In recent years, with books on social science and history flooding the publishing market, translators proposed renewed instructions as follows:

Chen yingnian and Xu shigu (1992:6), senior editors of commercial publishing house, points out that

"Academic translation prefers using the plain and standard language instead of dialects nor outdated words. To illustrate objective, one should us plain style of writing with directedness while rhetorical devices are discouraged." (Chen Y\& Xu S. Review and Status Quo in Philosophical and Social Science Translation, China Translation, 1992 (2).) The translation purpose he proposed is

"to faithfully convey the original author's thought and content, there is no need to reproduce emotion, verve, artistic conception, etc." (Ibid.)

Chen Caijun (2006:130) emphasized the practical significance of the selection of translation texts and the selection direction of editions.

As a branch of social science translation, the translation of historical texts presents its particularity and limitation. One of the practitioners of the translation of Chinese historical theories is the great historian Liang qichao, who put forward the following views on the translation of historical texts: "whoever translates a book will make people understand completely its hidden meaning and to avoid loss in meaning, what the translator has acquired in knowledge should approximate the knowledge of the original author". (Luo X\& Chen Y Ed, Analects on Translation. Beijing: Commercial Press, 2009., p.196.)

Li tiejiang (2001:98) pointed out the importance of preparing professional dictionaries and literature ahead of the translation process and emphasized that literal translation is the main method in the translation of historical works, and free translation can also be adopted. In the actual translation process, the translator should proofread, check mistakes, omissions, modify and embellish the translation and examine it thoroughly.

Lanqi (2002:19) put forward the following suggestions: 1. Proficiency in the native language. 2. Be Familiar with the relevant knowledge of the discipline, including the historical and cultural background knowledge, the main stream of thoughts, the frontier for development, etc.

In recent years, with the upsurge of translation of historical texts, a group of young scholars have emerged to further illustrate the characteristics, translation theories and skills to translate historical texts from different perspectives:

Duan Li Yi (2016) in his master's thesis, summarizes the difficulties that historical texts have caused to translation:

1. Large number of complex terminology and literature

2. Semantic ambiguity caused by cultural default, negligence of historical background or brief summarization.

3. Long difficult sentences and complex grammatical structure

Zhao Xiang-yun (2018:52) explores the historical text translation of cultural default of ChineseEnglish translation, introducing Toury's translation norms into the spectrum of historical translation, namely (Preliminary norms), (the Operational norms) and Initial specification (Initial norms) (Peter Newmark. A Textbook of Translation. Shanghai: Shanghai Foreign Language Education Press, 2001.) 
The study of the above scholars has enriched the theory of historical text translation and provided us with a practical guideline for historical translation.

\section{The Name and Affinity in the Translation of Historical Texts}

To translate historical-theory based texts, the first priority is the accurate naming of the title. He Lin, a renowned philosopher initiated the following principle:

"1.philological foundation is a must". 2. "It is necessary to have a good foundation of philosophy history, checking how a term has been used by philosophers throughout the history of philosophy, or how the term has been used by a philosopher in all his books. 3. When necessary, a new name may be coined for the purpose of translating a foreign name, but only with extreme care and detailed explanation.”. (Gao Q Ed. Collection of He Lin, Beijing: China People's University Press, 2014, p.196.) The accuracy of the translated name covers two levels. The first is to accurately translate the names involved. The naming of specific characters and specific events must conform to the cognition of academia and the public. David Ludden's An Agrarian History of South Asia has the following description of R.C. Dutt, a prominent political figure in British-India: "In middle-class university courses, history reflects nationality. R.C. Dutt (Da Te 达特) is an outstanding figure.” (David Ludden. the New Cambridge History of India, An Agrarian History of South Asia. Cambridge: Cambridge University Press, 2008, p.12.) British translator Newmark divides readers into three types: the expert, the educated layman, and the uninformed) (Newmark, 2001: 15). R.C.Dutt is a famous Indian economist, who has made in-depth and extensive research on the colonial system and policies in the British-Indian colonial period. The translation of his name into ( $\mathrm{Du}$ Te杜特) is more accurate and conforms to the widespread recognition of the academic community.

The title of the second translation should be clear-cut and reader-oriented. The titles of historical books translated in contemporary period are sometimes vague and puzzling. For instance, Peng Gang (2013: 32) translated the book "The Dilemma of Contemporary Anglo-Saxon Philosophy of History" (Frank AnkerSmit) into "The Dilemma of Contemporary English Philosophy of History", which would cause a confusion of the due concept. Since "Anglo-Saxon" is a historical concept, which cannot be used interchangeably with English or Brition. Professor Li Jianming's (2017:106) translated Clarence's book "The formative Years", as "The Age of Shaping", seems to be inappropriate. "Shaping". How to define the scope and spectrum of shaping and how is it achieved? The translation into "History of the Formation of America" will be more appropriate in readability and directionality. Similarly, Hayden White's "The burden of History" (Hayden White. Tropics of Discourse Essays in Cultural Criticism. Baltimore: John Hopkins University Press, 1987, p.27.) has been translated into "The Responsibilities of History" by many historians. However, after close reading, we found that the title inappropriate. This article mainly narrates the history which holds a neutral position in "art and science", "epistemology and methodology" and its historical position, responsibilities and functions after this neutral position is dissolved. Therefore, translating "burden" into "responsibilities" would produce unnecessary ambiguity for the readers. In authoritative dictionaries, such as the New English-Chinese Dictionary, "burden" means "gist, theme", while in Webster's Dictionary, "burden" means "an often repeated main point, message; On-line dictionary "Bing" also explained "the burden": "the main theme or gist of a speech, book, or argument, such as "the burden of his views". Here the definite article "the" emphasizes the particularity of its usage. Based on the explanations and the narrative theme of the article, the author proposes that translating the title "The burden of History" into "The Essence of Historiography" can better reflect the central meaning of the article and in line with the gist of the article.

\section{Book Title Translation and the Coherence of the Gist}

In David Ludden's, An Agrarian History of South Asia, "Nehru's Discovery of India determines order and power in the region by depicting geography" (David Ludden. the New Cambridge History of India, An Agrarian History of South Asia. Cambridge: Cambridge University Press, 2008, p.34.). 
In the book title, "India" is the theme of the discussion and the controlling idea of the author's interpretation. The Chinese Translation equivalents "Findings in India", which deviates from author's orientation. Therefore, a better naming is desirable for the book title.

Thirdly, in the process of translation, the changes of the ancient and modern meanings of words should also be considered. Professor Li Jianming cited Thomas Paine's book The American Crisis when talking about historical semantics and interpretation of historical materials in his article Crossshore view. In the context of the 18th century, the English word "crisis" can refer to: 1. A turning point, as in a sequence of events, for better or for worse. SDX Joint Publishing Company translate the book into The American Crisis 《美国危机》 is a misunderstanding of the original meaning.

Technical terms are also a focus of historical translation. Translators should pay special attention to the use of technical terms, in the book An Agrarian History of South Asia, David Ludden mentions "This semi-arid landscape consists of river basins... underground water tucked away in the rocky substrate of the Deccan Trap" (David Ludden. the New Cambridge History of India, An Agrarian History of South Asia. Cambridge: Cambridge University Press, 2008, p.57.) Deccan Trap does not mean a trap, but refers to the "Deccan Rock Group". It is a must for the translator to trace the exact meaning according to the context of the historical writing.

\section{Cultural Context and Seriousness of Historical Texts}

In the 1990s, with the prevalence of "cultural turn", cultural factors have become an indispensable and crucial component of translation studies. Venuti, a prominent figure in post-translation studies, advocates the principle of "foreignizing translation". He believes in the process of translation; efforts should be made to preserve the linguistic and cultural differences between the original and the translated text to make the translated text "Bend toward a foreign likeness." (Lawence Venuti, The Tanslator's invisibility A history of translation. Routledge, 1995, p.101). The adoption of the method "domestication" or "foreignization" depends on "a specific cultural formations where discourse is canonized or marginalized, circulating in relations of domination and exclusion." (Ibid. p.102). This theory applies to the translation of historical documents. While the translator exerts his subjective initiative, it is more important to maintain the integrity and theoretical nature of the original text so as to sustain the unity of seriousness and professionalism of the original text.

The Sage Handbook of Historical Theory, published in 2013 by Sage Publications Ltd., and jointly translated and by Shanghai People's Publishing House covers the latest theoretical research of postmodern and post-postmodern historiography. In the introduction written by Nancy Partner, there is such an original sentence written in English:

"Historical theory is a coherent yet flexible framework which supports the analysis of historical knowledge, and assists our under-standing of what kind of knowledge we can have of the past, and precisely how that knowledge is constructed, assembled, and presented" ( Nancy Partner and Sarah Foot Ed, The Sage Handbook of Historical Theory, Sage Publications Ltd., 2013, p.1.).

Two translators of this book translated it as: “史学理论是一套严密规整但又有所弹性的框架 组织, 它支撑着历史知识分析, 并有助于我们能获得怎样关于过去的知识, 确切地说, 即知 识是如何被建构、编排和表达的” (Parnter, N \&Foot, S. (2017). Shi Xue Li Lun Shou Ce (Yu. W\& He. L Trans.) Shanghai: Shanghai People's Press. (Original Work Published in 2013), p.1.). At first glance, the translation is clear and readable, but the author ignores the word "framework", which can be translated into "system, structure" and so on. "Historical knowledge" does not only refer to "historical knowledge", but also can be extended to "historical research". The second "knowledge" appearing in the article refers to "knowledge" of past acknowledgement. Only when the specific meaning of a word is introduced into a specific context in the translation process, can the true meaning of original text be obtained. The above translation may be amended to read:

史学理论是一套连贯而灵活的体系, 其为历史研究的分析提供支持, 促进我们对过去认 识的理解, 以及这种认识是如何构建、组织和呈现的。

Another paragraph in the article's introduction reads: "history's modernity the university-based historian was, for the first time, a trained professional who had mastered the difficult techniques of 
archival research.” (Nancy Partner and Sarah Foot Ed, The Sage Handbook of Historical Theory, Sage Publications Ltd., 2013, P.3.).

The translation is: “如历史学的现代性, 肇始于19世纪其进入大学作为一门教授与研究科目。 以大学为基地的历史学家, 首次成为经过训练掌握不同档案研究技能的专业人士” (Parnter, N\& Foot, S. (2017). Shi Xue Li Lun Shou Ce (Yu. W \&He. L Trans.) Shanghai: Shanghai People's Press. (Original Work Published in 2013), p.4.) In the process of translation, the translator is confused about the meaning of the word "techniques of archival research", while "teaching and research subjects" are confusing. At the same time, the word "base" in "university-based" has the meaning of "based on" and "foundation". Hence, the author has utilized the transferred meaning to make it more flexible and life-oriented. We hereby revise to read as follows:

历史学之现代性起源于在 19 世纪其进入大学成为教学及研究科目, 进入大学的历史学家首 次成为经过训练、掌握文献分析法的专业人士.

To summarize, the author believes that historical translation is a product of meaning transformation between the source language and the target language, which could be influenced by many factors, such as the quality and style of the translator. Mastery of the source language and the target language by the translator's; Political, economic, social and cultural influences, etc. In order to achieve the affinity between the translated texts and the original counterpart, first of all, we should consider the background of the text to present the style and features of the author's choice of words and sentences. Secondly, we should consider the background of the text and the author's intention in detail. We should adopt the corresponding "Decoding" strategy for different styles. Only in this way can we achieve the "affinity" to the greatest extent and realize the organic unity of the translated text and the Discourse language by the author's "original intention".

Thirdly, meaning is a pluralistic and accidental relationship, rather than a unitary and unchangeable nature (venuti: 2009). In the process of translation, mistakes like mistranslation, translation omission and deliberate digression in writing are inevitable. Only when the translator truly perceives the intention of the author can he present the translated works with the highest degree of affinity to the readers.

Historical documents are an important part of history, and the translation of foreign theories is still an important part of the disciplinary construction of world history in several years. (Liu Beicheng: 2011). We should attach importance to the quality of translation and be familiar with translation theory. Only in this way can we achieve the affinity between text and meaning in translation history works and achieve the unity of the original text and the target language.

\section{References}

[1]. Anonymous. Research and Investigations in Historiography: Analects Publishing by the History Division of Social Science Commission of Ministry of Education. Beijing: Beijing Normal University Press, 2011.

[2]. Bassnett, Susan. Translation Studies (Third Edition). Shanghai: Shanghai Foreign languages Press, 2001.

[3]. Chen C. On Translation of Academic Works, Academic Research. 2006 (9).

[4]. Chen Y\& Xu S. Review and Status Quo in Philosophical and Social Science Translation, China Translation, 1992 (2).

[5]. Duan L. A Study of Xin-Da-YA IN Translation of Historical Material, An Excerpt from the Making of Japan. (Dissertation). Nanjing: Nanjing University, 2016.

[6]. Dutt, Romesh Chunder. The Economic History of India Under Early British Rule: From the Rise of The British Power In 1757, To the Accession of Queen Victoria in 1837. Palala Press, 2015.

[7]. Gao Q Ed. Collection of He Lin, Beijing: China People's University Press, 2014. 
[8]. Gao Y et. al., the New English-Chinese Dictionary, Shanghai Translation Publishing House, 2013.

[9]. Gentzler, Edwin. Contemporary Translation Theories. Shanghai: Shanghai Foreign languages Press, 2004.

[10]. Lan Q. Some Translation Issue of Academic Works, Discussion of Due Issue with Mr. Wei Liang Tao. Journal of Historical Science, 2002 (5).

[11]. Li J. Xue Shu de Zhong Yu Qing. Beijing: Commercial Press, 2017.

[12]. Li T. A Discussion of the Translation of Historical Works: Taking History of Persian Empire and Iran History for Example. Journal of Changshu Institute of Technology (Philosophy \& Social Sciences).2011 (1).

[13]. Ludden, David. the New Cambridge History of India, An Agrarian History of South Asia. Cambridge: Cambridge University Press, 2008.

[14]. Luo X\& Chen Y Ed, Analects on Translation. Beijing: Commercial Press, 2009.

[15]. Multiple Authors. Random House Webster's College Dictionary 2nd Edition. Random House Inc., 1999.

[16]. Newmark, Peter. A Textbook of Translation. Shanghai : Shanghai Foreign Language Education Press, 2001.

[17]. Nida, Eugene A. Language and Culture Context in Translating. Shanghai: Shanghai Foreign languages Press, 2001.

[18]. Snell-Hornby, Mary. Translation Studies an Integrated Approach. Shanghai: Shanghai Foreign languages Press, 2001.

[19]. Partner, Nancy\& Foot Sarah Ed, The Sage Handbook of Historical Theory, Sage Publications Ltd., 2013.

[20]. Parnter, N \& Foot, S. (2017). Shi Xue Li Lun Shou Ce (Yu. W\&He. L Trans.) Shanghai: Shanghai People's Press.(Original Work Published in 2013).

[21]. Venuti, Lawence. The Tanslator's invisibility A history of translation. Routledge, 1995.

[22]. White, Hayden. Tropics of Discourse Essays in Cultural Criticism. Baltimore: John Hopkins University Press, 1987.

[23]. Wolfram, Wilss. The Science of Translation, Problems and Methods. Shanghai: Shanghai Foreign languages Press, 2001.

[24]. Zhao X. The Changes and Motives of the Norms in Chinese-English Translation of Works of National Leaders in China, with Translation of Book Titles of National Leaders, Shanghai Journal of Translators. 2018 (6). 